\title{
The impact of using batteries in micro PV system on profitability of the investment
}

\author{
Bartosz Chwieduk ${ }^{1 *}$, and Michat Chwieduk ${ }^{2}$ \\ ${ }^{1}$ Warsaw University of Life Science - SGGW, Department of Fundamenal Engineering, \\ ul. Nowoursynowska 164, 02-787 Warsaw \\ ${ }^{2}$ Warsaw University of Technology, Institute of Heat Engineering, Division of Refrigeration and \\ Energy in Buildings, ul. Nowowiejska 21/25, 00-665 Warsaw
}

\begin{abstract}
The paper presents the results of calculations of energy consumption and economic analysis of the operation of micro photovoltaic installations. Calculations have been made for a single-family house with an energy demand based on real electricity consumption. Two cases have been considered. In the first one, the photovoltaic system contains only PV modules and an inverter. Energy produced is sent to the power grid. In the second case, the PV system also contains batteries. Because of existing regulation conditions, it is better to accumulate produced energy than to sell it to the grid. Costs of construction of the PV systems and money savings during operation of the PV systems have been compared. Conclusions of profitability of analyzed systems have been presented.
\end{abstract}

\section{Introduction}

Over the last few years, interest of construction and operation of PV micro installations has been increased. Photovoltaic systems with power up to $40 \mathrm{kWp}$ are called micro installations. In Poland in 2017, the total power of micro photovoltaic systems increased from 91.5 MWp in January to $171 \mathrm{MWp}$ at the end of the year. There are more then 27,000 micro installations connected to the power grid [1]. Most of photovoltaic systems are put on the roof of single family houses and they usually do not accumulate produced energy in batteries. Energy generated by the PV modules is fully transferred to the power grid. Single-family houses with photovoltaic micro installations usually are located far from large agglomerations. They are located at the ends of a low voltage grid. People living in such buildings are exposed to temporary cuts of access to electricity. Often, because of bad weather conditions, a low voltage grid can be broken for a few hours. The results of calculations presented in the paper deal with a house located near Warsaw, where at least ten times per year there are difficulties accessing electricity. Usually, electricity cuts take several hours. During the day, the energy produced by photovoltaic system can power some of the devices in the building. If PV installation does not contain any batteries, after sunset the households do not have access to electricity. This problem can be solved by adding energy storage to the photovoltaic system. When electricity from the grid is available, the

* Corresponding author: bartosz_chwieduk@sggw.pl 
batteries are fully charged. Energy storage works only when there is no access to electricity from the grid.

\section{Electricity demand}

In the selected single-family house, several devices based on renewable energy sources have been applied. A heat pump and solar collectors are working for the space heating and domestic hot water needs. For heating or cooling the ventilation air recuperator (heat exchange unit) has been used. Based on the electricity consumption and time of operation of devices installed in the building an hourly demand for electricity has been calculated. Figures 1 and 2 show the electricity demand on the $1^{\text {st }}$ of January and the 1 st of July. High demand for electricity during winter is caused by the heat pump operation. It is the only source of heat for the space heating. The heat pump's working hours have been adapted to maximize the use of electricity from the photovoltaic system [2,3]. Because of current legal regulations it is better to use the energy from the PV system for one's own use, without directing it to the grid [4]. The daily demand for electricity in the winter period has been estimated to be in range of 30 to $40 \mathrm{kWh}$. The highest demand for electricity occurs in December and it is around $1,200 \mathrm{kWh}$. In this period ambient temperature is the lowest. The heat pump works for space heating and DHW and uses energy up to 12 hours during a day.

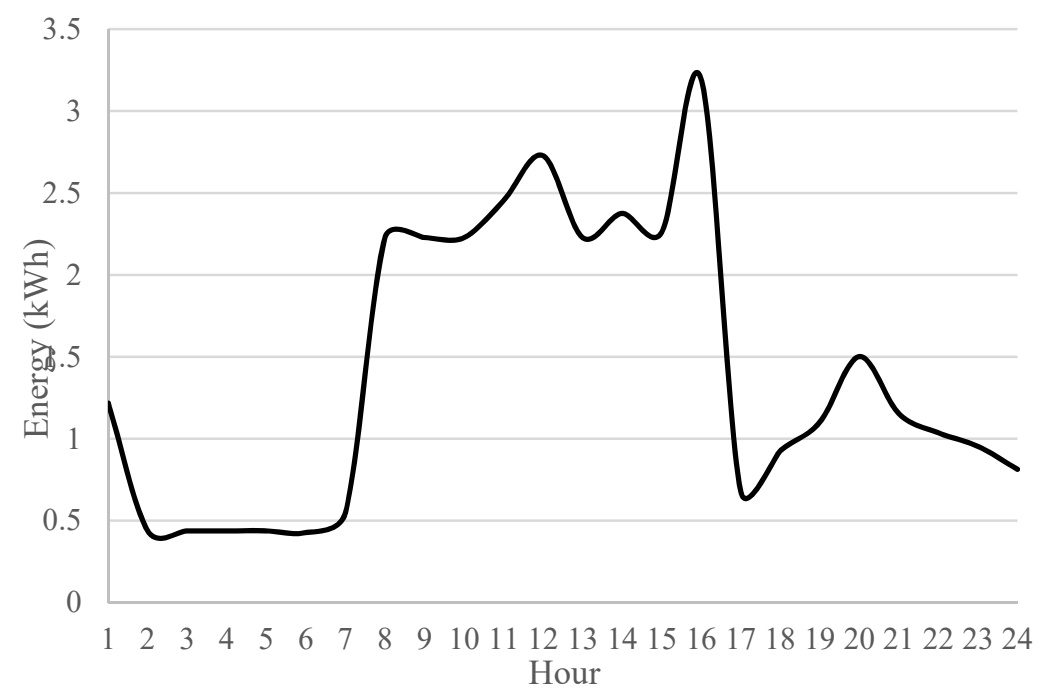

Fig. 1. Electricity needs on January $1^{\text {st }}$. 


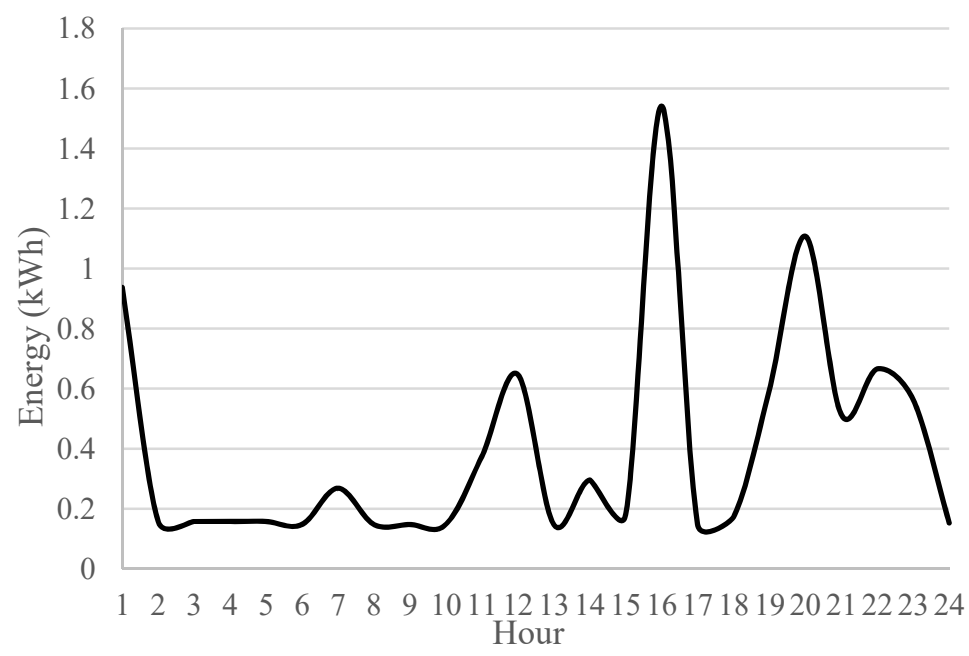

Fig. 2. Electricity needs on July $1^{\text {st }}$.

Figure 2 clearly shows the hours when electricity needs are increasing. The large energy demand in the afternoon and evening is a result of the intensive activity of the household. Most of the family members return home around $4 \mathrm{pm}$. From 2 to 9 am energy demand is the lowest and it is below $200 \mathrm{Wh}$ per hour. The daily electricity needs in July are about $10 \mathrm{kWh}$. Total yearly energy demand is equal to $8,000 \mathrm{kWh}$.

\section{Selection of photovoltaic system}

Two cases of PV systems have been considered. In the first case, the most important elements of a PV system are photovoltaic modules and a string inverter. Energy generated by modules is transferred directly to the grid. In the second case, micro installation additionally contains batteries. They work as electric energy storage. Figure 3 and 4 present the schemes of photovoltaic systems considered in the paper.

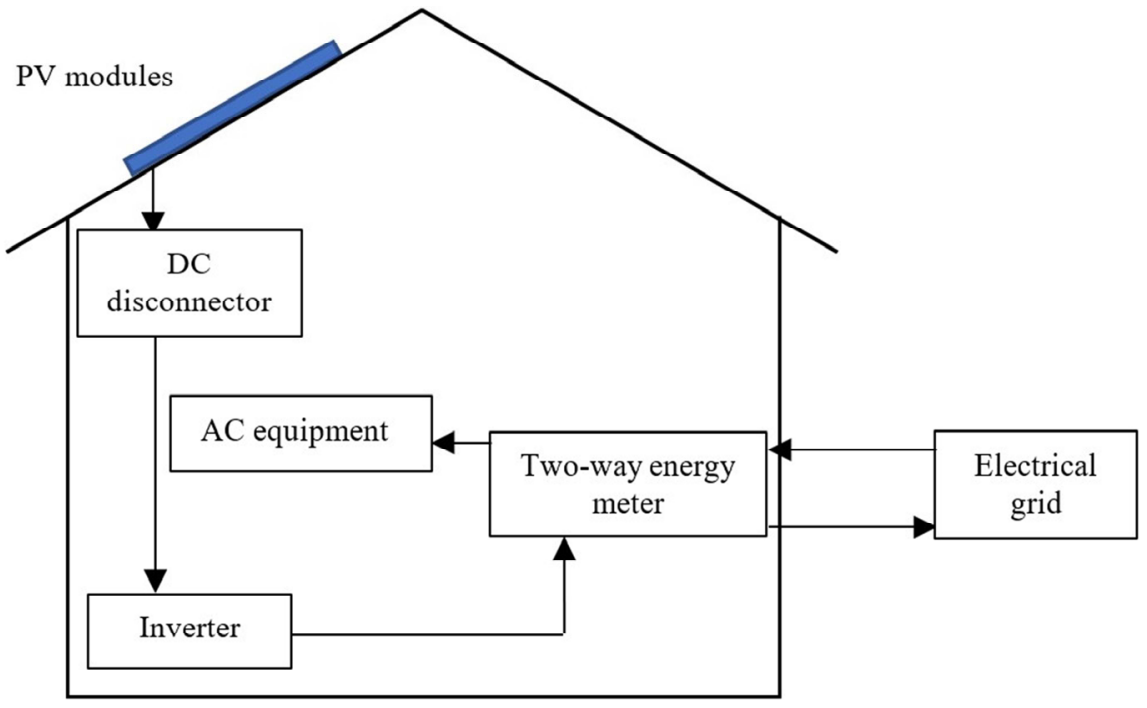

Fig. 3. Schema of a photovoltaic installation without energy storage. 


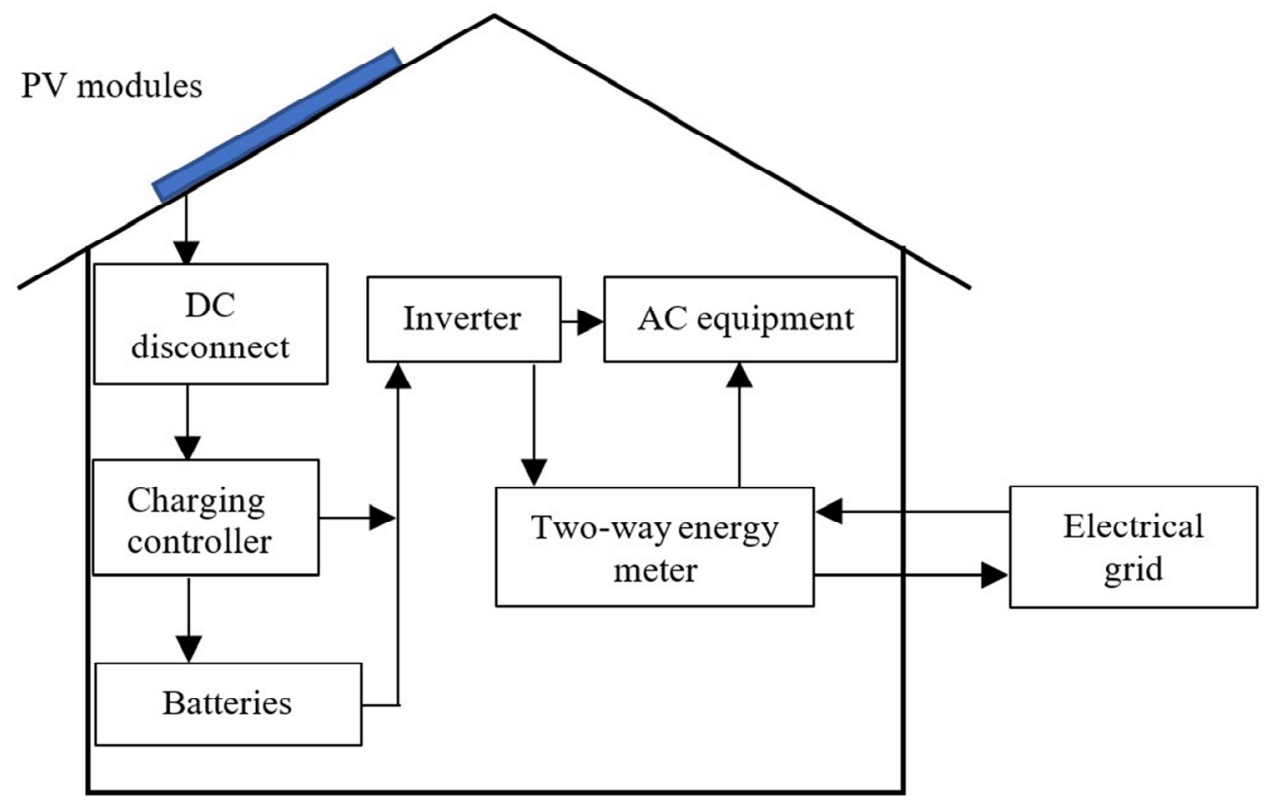

Fig. 4. Schema of a photovoltaic installation with energy storage.

Many factors and parameters have an impact on nominal planned power of a photovoltaic system. If the owner of the PV installation wants to be able to use financial support schemes, then the nominal power of installation cannot be higher than $40 \mathrm{kWp}$ [4]. Because most micro installations are located on a roof of the building, the size of the system is limited by the available area of the roof. PV modules of a total power equal to $40 \mathrm{kWp}$ cover a roof surface of approximately $230 \mathrm{~m}^{2}$. In the considered single-family house, the area of the roof which can be used for photovoltaic installation is $45 \mathrm{~m}^{2}$. One of the most important parameters, which usually has a decisive impact for a nominal power of installation is the payback period. Due to legal regulations it is preferred for users of PV system to consume the produced energy for they own needs. The more that the energy gained by the photovoltaic system is used by the household, the greater its financial savings are.

The most commonly used method to calculate the size of a micro installation connected to the grid is based on equality of energy demand of the household and energy production from PV system for a whole year. In the described system sizing was made based on maximal direct use of energy produced by the PV system. It was assumed that for each month, energy produced by the PV system will be equal or lower than energy demand. At first, the ratio of monthly electricity demand to solar gains needs to be calculated. The "best" month is a month with the smallest ratio and this month was used to size whole system. In the selected month, the amount of energy produced by the photovoltaic system should be nearly the same as the electricity demand. Users of the installation, in which size was calculated in that way, can use about $30 \%$ of electricity produced by the solar system [5]. The rest of the energy gained by the PV system should be transferred to the grid. In the considered building, a heat pump is used to heat the rooms during the heating season. The cooperation of a photovoltaic installation and the heat pump allows one to directly use more energy generated by the system.

Based on meteorological data of solar irradiation downloaded from the Ministry of Investment and Development website and demand for energy of a selected house, the power of a PV system should be calculated for June [6]. 
Calculation of the size of photovoltaic systems start from batteries. In the first case under consideration, the PV system does not have an energy storage. All produced energy is transferred directly to the inverter and then to the grid.

In the second case the photovoltaic system is more complicated. One of the elements of this system is a set of batteries. Batteries are a backup, emergency source of energy. They are used only when there is no energy supplied from the grid. The calculations assume that power outages will last no longer than 6 hours. If during the heating season, energy is coming from the batteries the heat pump automatically switches off. In this period only the necessary devices and lighting are working. It has been estimated that the average daily electricity demand when photovoltaic installation works as off grid system, is $9 \mathrm{kWh}$.

$$
Q_{c}=\frac{E \cdot t}{U \cdot D}
$$

$Q c$ - capacity of batteries (Ah),

$E$ - average daily energy demand (kWh/day),

$U$ - nominal system voltage $(\mathrm{V})$,

$t$ - time of pv system work as off-grid installation (h),

$D$ - maximum depth of battery discharge.

The nominal system voltage is $24 \mathrm{~V}$ and the maximum depth of battery discharge is 0.7 . Usually the depth of discharge of batteries should not exceed 0.3 . This guarantees the correct operation of batteries for 8-10 years. The batteries are charging during the day and discharging when the PV modules do not produce energy. In the considered case, the batteries will be unloaded only several times a year. The number of charging and discharging cycles during the lifetime of the installation will not exceed 500. The required capacity of batteries is $3.2 \mathrm{kWh}$. Nominal voltage of the PV system is $24 \mathrm{~V}$, so capacity of batteries needs to be at least $135 \mathrm{Ah}$. Two batteries made in gel technology HZY EV $12 \mathrm{~V}-135 \mathrm{Ah}$ [7] with a capacity of $135 \mathrm{Ah}$ each were selected for calculation. As the nominal voltage of the photovoltaic system is $24 \mathrm{~V}$, it is necessary to use two batteries connected in series.

To determinate power of the photovoltaic system, it is necessary to calculate solar gains. Using the isotropic solar irradiation model [8], hourly solar irradiation on the roof surface of a building has been calculated. The roof is directed to the south and tilted at angle of $38^{\circ}$ to the horizontal surface. Total solar irradiation gains in June on the roof surface is $150 \mathrm{kWh} / \mathrm{m}^{2}$. The demand for electricity in June is $375 \mathrm{kWh}$. At this stage of predicting the size of the system, the photovoltaic modules need to be selected. The power of the system will depend on efficiency and power of a single module. QCELLS G4.3 module with power of $285 \mathrm{Wp}$ and $17.1 \%$ efficiency [9] was selected for calculations. The calculated power of installation is $2.85 \mathrm{kWp}$. The system contains 10 photovoltaic modules. If there is no energy storage (no batteries) in the PV system, the photovoltaic modules are connected in series. For such a PV generator the SMA Sunny Boy 3.0 string inverter [10] was selected. If the photovoltaic system contains batteries, the method of connecting the modules depends on a parameter of the selected charging regulator. In the considered case, a hybrid inverter, [11] which at the same time can work as a charging regulator, was selected. An inverter can control the flow of electricity from the photovoltaic system. It can direct energy from modules or batteries to the grid or devices in the building. The maximum current which can flow through a charging regulator/inverter is $18 \mathrm{~A}$. The maximum allowed voltage of the PV generator is $360 \mathrm{~V}$. In this type of a system, the modules will be connected in one series. 


\section{Energy gains from the system}

Using the meteorological data from the Ministry of Investment and Development website, the solar irradiation isotropic model and technical data of selected components [12], the energy gains from the photovoltaic installation have been calculated. All calculations were made with an hourly time step. In the first case, when the system does not include batteries, all energy produced by the photovoltaic modules is directed to the grid. If one of the elements of the system is a hybrid inverter, the energy gained can also supply devices in a building. The working hours of a heat pump have been adapted to maximize the use of electricity from the PV installation. Because of that, only $55 \%$ of total energy generated annually will be transferred to the grid. Table 1 presents the annual energy gains from the photovoltaic system, the amount of energy that can be used by the household, the amount of energy that will be directed to the grid and the energy bought from the grid operator. If the photovoltaic system does not include the energy storage and is directly connected to the grid, all the produced energy is transferred to the grid. Energy gains are decreasing, because the efficiency of photovoltaic modules is changing in time [13].

Table 1. Energy produced by the PV system, used by household, transferred to the grid and bought from the grid operator.

\begin{tabular}{|c|c|c|c|c|}
\hline Year & $\begin{array}{l}\text { Energy produced } \\
\text { by PV system } \\
\text { (kWh/year) }\end{array}$ & $\begin{array}{c}\text { Energy used } \\
\text { by household } \\
\text { (kWh/year) }\end{array}$ & $\begin{array}{c}\text { Energy transferred } \\
\text { to the grid } \\
\text { (kWh/year) }\end{array}$ & $\begin{array}{l}\text { Energy bought from } \\
\text { the grid operator } \\
\text { (kWh/year) }\end{array}$ \\
\hline 1 & $2,876.5$ & $1,294.4$ & $1,582.1$ & $6,705.6$ \\
\hline 2 & $2,853.5$ & $1,284.1$ & $1,569.4$ & $6,715.9$ \\
\hline 3 & $2,830.6$ & $1,273.8$ & $1,556.8$ & $6,726.2$ \\
\hline 4 & $2,808.0$ & $1,263.6$ & $1,544.4$ & $6,736.4$ \\
\hline 5 & $2,785.5$ & $1,253.5$ & $1,532.0$ & $6,746.5$ \\
\hline 6 & $2,763.2$ & $1,243.4$ & $1,519.8$ & $6,756.5$ \\
\hline 7 & $2,741.1$ & $1,233.5$ & $1,507.6$ & $6,766.5$ \\
\hline 8 & $2,719.2$ & $1,223.6$ & $1,495.6$ & $6,776.4$ \\
\hline 9 & $2,697.5$ & $1,213.9$ & $1,483.6$ & $6,786.1$ \\
\hline 10 & $2,675.9$ & $1,204.2$ & $1,471.7$ & $6,795.8$ \\
\hline 11 & $2,654.5$ & $1,194.5$ & $1,460.0$ & $6,805.5$ \\
\hline 12 & $2,633.2$ & $1,184.9$ & $1,448.3$ & $6,815.1$ \\
\hline 13 & $2,612.2$ & $1,175.5$ & $1,436.7$ & $6,824.5$ \\
\hline 14 & $2,591.3$ & $1,166.1$ & $1,425.2$ & $6,833.9$ \\
\hline 15 & $2,570.5$ & $1,156.7$ & $1,413.8$ & $6,843.3$ \\
\hline 16 & $2,550.0$ & $1,147.5$ & $1,402.5$ & $6,852.5$ \\
\hline 17 & $2,529.6$ & $1,138.3$ & $1,391.3$ & $6,861.7$ \\
\hline 18 & $2,509.3$ & $1,129.2$ & $1,380.1$ & $6,870.8$ \\
\hline 19 & $2,489.3$ & $1,120.2$ & $1,369.1$ & $6,879.8$ \\
\hline 20 & $2,469.3$ & $1,111.2$ & $1,358.1$ & $6,888.8$ \\
\hline 21 & $2,449.6$ & $1,102.3$ & $1,347.3$ & $6,897.7$ \\
\hline 22 & $2,430.0$ & $1,093.5$ & $1,336.5$ & $6,906.5$ \\
\hline 23 & $2,410.6$ & $1,084.8$ & $1,325.8$ & $6,915.2$ \\
\hline 24 & $2,391.3$ & $1,076.1$ & $1,315.2$ & $6,923.9$ \\
\hline 25 & $2,372.1$ & $1,067.4$ & $1,304.7$ & $6,932.6$ \\
\hline 26 & $2,353.2$ & $1,058.9$ & $1,294.3$ & $6,941.1$ \\
\hline 27 & $2,334.3$ & $1,050.4$ & $1,283.9$ & $6,949.6$ \\
\hline 28 & $2,315.7$ & $1,042.1$ & $1,273.6$ & $6,957.9$ \\
\hline 29 & $2,297.1$ & $1,033.7$ & $1,263.4$ & $6,966.3$ \\
\hline 30 & $2,278.8$ & $1,025.5$ & $1,253.3$ & $6,974.5$ \\
\hline Sum: & $76,992.9$ & $34,646.8$ & $42,346.1$ & $20,5353.2$ \\
\hline
\end{tabular}




\section{Investment and running costs of the photovoltaic system}

Results of the calculations presented in the paper consider two different installations. In first one, there is no possibility to accumulate energy. The second one contains two batteries which create the energy storage. Each of them contains 10 photovoltaic modules. The price of a single module is 650 PLN. In the system which produces energy to the grid, there is a string inverter. Cost of inverter is 4,000 PLN. In an installation with an energy storage unit, it is necessary to use a hybrid inverter. The price of selected inverter is 4,800 PLN. Additionally, the system contains 2 batteries. The price of the energy storage unit is 2,720 PLN. The total price of the photovoltaic system also includes:

- transport and montage of installation elements,

- supporting construction for modules on the roof of a building,

- electric emergency protection.

Table 2 puts together the prices of all components of the building system.

Table 2. Prices of components of the building system based on references [5, 7, 9-11, 14].

\begin{tabular}{|l|c|c|}
\hline \multicolumn{1}{|c|}{ Component } & $\begin{array}{c}\text { System without } \\
\text { energy storage (PLN) }\end{array}$ & $\begin{array}{c}\text { System with energy } \\
\text { storage (PLN) }\end{array}$ \\
\hline Photovoltaic modules & 6500 & 6500 \\
\hline Batteries & - & 2720 \\
\hline Inverter & 4000 & 4800 \\
\hline Transport and montage & 2500 & 3000 \\
\hline Frame system & 2000 & 2000 \\
\hline Electric protection & 500 & 500 \\
\hline Sum: & $\mathbf{1 5 5 0 0}$ & $\mathbf{1 9 5 2 0}$ \\
\hline
\end{tabular}

Except for the costs of construction the PV system, the household has to reckon with running costs of the system. The cost of annual inspections of the PV system should not exceed $250 \mathrm{PLN}$. The insurance of installations with a power of about $3 \mathrm{kWp}$ is about $0.25 \%$ of its gross value. In this case it means around 50 PLN. After 15 years of using photovoltaic installation it will be necessary to replace the inverter. Based on price fluctuations of photovoltaic inverters in last years, the annual price drop has been estimated to achieve level of $2 \%$. This means that the cost of replacing an inverter will be 3,000 PLN or 3,500 PLN depending on its type.

\section{Economic analysis}

In the economic analysis it was assumed that the owner of the installation can use the support system for photovoltaic micro installations. Currently, net metering is the only nationwide available form of the support for such a system [4]. In a semi-annual net metering scheme the electricity grid is treated as an energy storage operating with a certain efficiency. Electricity produced by a photovoltaic system is transferred to the grid. In the first considered case, all produced energy is directed to the grid. In the second one, $45 \%$ of energy produced is used by the household. The owner of the PV system can deduct that $80 \%$ of the photovoltaic energy produced by his system can be transferred to the grid. In the place where the considered building is located, net metering is currently the only available support form for photovoltaic micro installations. In many places, regional support and co-financial systems for photovoltaic installations are available. However, a future owner of an installation should remember that he can only use one of those support system. If the 
prosumer obtains co-financing for PV installation, he cannot at the same time take benefits from the net metering. In the first year of the PV system operation, the energy price is 0.55 PLN for $1 \mathrm{kWh}$. Based on the history of electricity prices, its annual growth can be estimated at $2.6 \%$ [15]. Figure 5 shows the financial savings coming from the operation of the photovoltaic system. The line marked with the letter "a" refers to the case when all produced energy is directed to the grid. The lines with the letter "b" refer to the installation in which part of the energy is transferred to the grid and the rest is used by the household. There are three lines marked with letter " $b$ ": one that shows total savings for this scenario, savings due to energy transferred to the grid and savings doe to energy directly used by household.

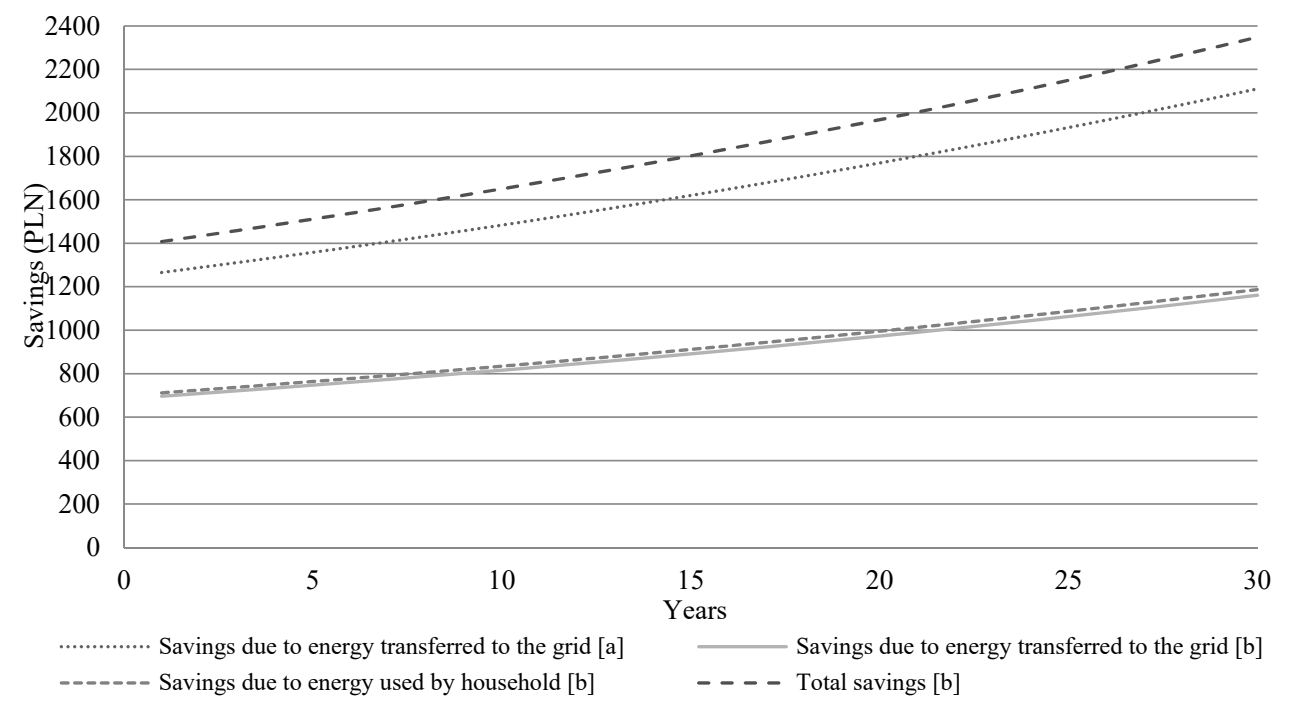

Fig. 5. Savings coming from work of the photovoltaic installation.

Figure 5 shows the savings coming from the direct use of energy produced by the PV system. They are higher than those coming from transferring it to the grid. Using $1 \mathrm{kWh}$ of energy directly without transferring it to the grid, household saves the equivalent of $1 \mathrm{kWh}$ energy bought from the grid operator. Inhabitants directing energy to the grid save only the equivalent of $0.8 \mathrm{kWh}$. In the selected building $55 \%$ of energy produced by photovoltaic installation can be transferred to the grid. Due to the increase of prices of electricity in the following years, financial savings from the PV system will grow. After the first year of the system operation, the financial savings will amount to 1,265 PLN or 1,408 PLN depending on the type of the system. In the thirtieth year of the system operation, taking into account the decrease in the efficiency of photovoltaic modules, saving will increase up to 2,110 PLN or 2,348 PLN.

Figure 6 shows the total savings after sequent years of the system operation. 


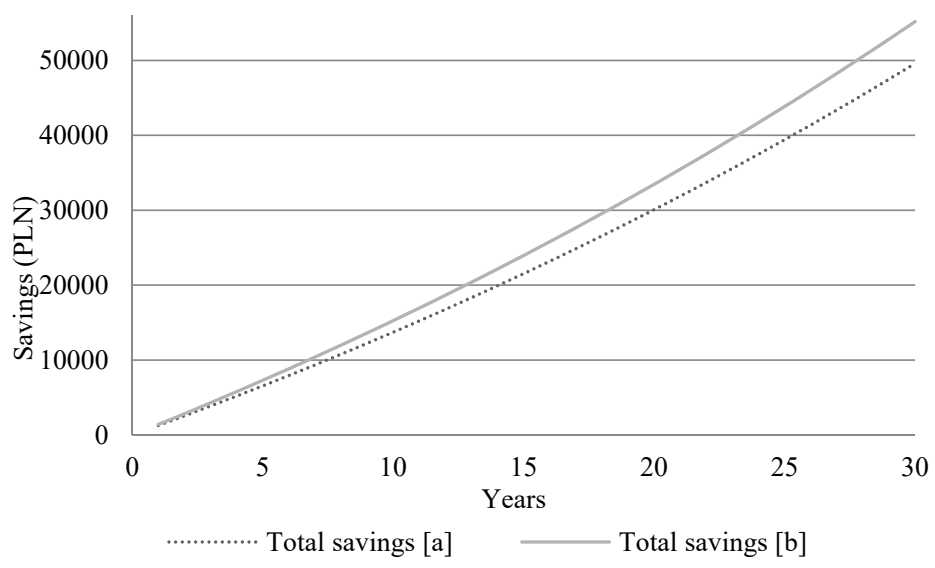

Fig. 6. Total savings after sequent years of the system operation.

After 30 years of the system operation, savings will amount to approximately 50,000 PLN for installation directly connected to the grid and 55,000 PLN for installation with energy storage.

Based on the results of the calculations presented in figure 5 and 6 and running costs of the system, the net present value NPV has been determined.

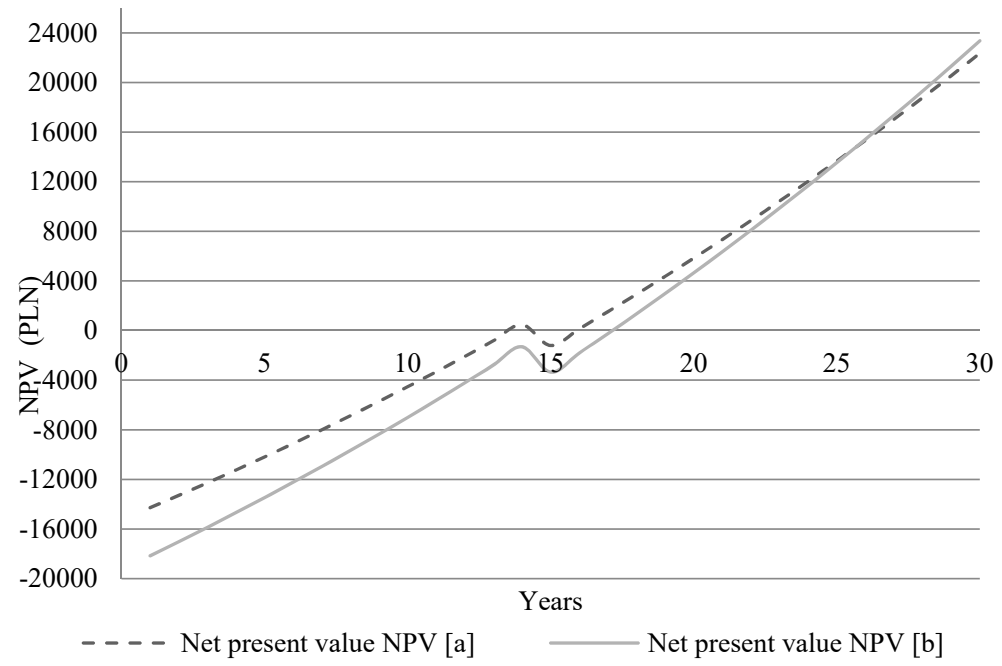

Fig. 7. Net present value NPV for the considered system.

The investment costs of the photovoltaic system, which cannot accumulate energy, will return financially after 14 years of its operation. Considering installation with batteries, NPV index will be higher than 0 after 17 years. After 15 years of the system operation, the photovoltaic inverter must be replaced. In the first case, when energy flows directly to the grid, because of the cost of replacement of an inverter, the NPV value (after 15 years) will drop below 0. One year after replacement of the inverter, the NPV index again will be positive and equal $140 \mathrm{PLN}$. In case of the installation with batteries, replacement of the inverter extends the installation's payback time by two years. After thirty years of the system operation, the NPV index will be equal to 22,400 PLN for installation without energy storage and 23,400 PLN for this one with batteries. 


\section{Summary and conclusions}

Of course investment costs of a photovoltaic system containing an energy storage unit are higher than for that one without batteries. It is necessary to use a hybrid inverter, that can at the same time transfer energy to the grid, direct it to devices in a building or to batteries. The capacity of the batteries has been calculated assuming that they would operate as an emergency energy supply, working only when there is no energy from the grid. This way of determining the size of energy storage reduced its impact on the total investment costs of the installation. The price of a hybrid inverter is $20 \%$ higher than the price of a string inverter [16]. The investment cost of the entire installation in this case is $26 \%$ higher. The price of photovoltaic modules has a large impact on the cost of the whole system and it's payback time. For energy performance and economic analysis modules with a relatively low price have been selected. There are also modules with a price over 1,300 PLN.

Hybrid inverter gives a possibility to use generated energy immediately without directing it to the grid. After 25 years of using photovoltaic system, the NPV index becomes higher for installation with batteries. After 30 years of the system working, the net present value NPV will be higher by 1,000 PLN. The great advantage of using photovoltaic installation with batteries is the constant access to electricity, even in the lack of energy from the national grid. One of possibility to reduce the payback time of a photovoltaic system can be increasing its nominal power. The costs of montage and annual inspections will have a lower influence on economic balance. Over the entire lifetime of an installation, the costs of inspections and insurance will be equal to nearly 9,000 PLN. It is $60 \%$ of the investment costs of the installation. For a system with a power of about $4 \mathrm{kWp}$ those costs are approximately equal to $40 \%$ of the total investment costs.

\section{References}

1. Stowarzyszenie Branży Fotowoltaicznej (http://polskapv.pl/)

2. B. Chwieduk, JCEEA, 63 (4/16), 53-60 (2016)

3. B. Chwieduk, D. Chwieduk, 12th IEA Heat Pump Conference 2017, ISBN 978-909030412-0, 1-10 (2017)

4. Ustawa z dnia 20.02.2015 o odnawialnych źródłach energii Dz. U. 2015 poz. 478

5. B. Szymański, Małe instalacje fotowoltaiczne, (Globenergia, Kraków 2013)

6. http://miir.gov.pl/

7. https://www.akumulatory-zelowe.pl/akumulator-zelowy-hzy-ev-12v-135ah-p-19.html

8. J. A. Duffie, W. A. Beckman, Solar Engineering of Thermal Processes, (John Wiley \& Sons, Inc., 1999)

9. http://recost.pl/panel-modul-fotowoltaiczny-qcells-g43-285w-p-185.html

10. https://sunsol.pl/assets/Uploads/SB1AV-40.pdf

11. https://www.sklep.asat.pl/pl/p/Inwerter-Hybrydowy-SKYMAX-HYBRID-3kW/435

12. F. Brihmat, S. Mekhtoub, Conférence Internationale des Energies Renouvelables "CIER'13", International Journal of Scientific Research \& Engineering Technology, (2014)

13. D. C. Jordan, S. R. Kurtz, NREL/JA-5200-51664, (2012)

14. https://fotowoltaiczne.info/jakie-ceny-za-montaz-paneli-fotowoltaicznych/

15. Informacyjny Serwis Biznesowy (www.isbnews.pl)

16. PHOTOVOLTAICS REPORT Fraunhofer Institute for Solar Energy Systems, ISE 26 February 2018 